\title{
Pengaruh Penggunaan Handphone (Android) Terhadap Motivasi Belajar Siswa Kelas Xi Di Sma Negeri 1 Lintongnihuta
}

\section{The Influence of Cellphone Use (Android) on the Learning Motivation of Class Xi Students at SMA Negeri 1 Lintongnihuta}

\author{
Naffesa* \\ Fakultas Psikologi, Universitas Medan Area, Indonesia \\ Disubmit: 29 Maret 2021; Diproses: 29 Maret 2021; Diaccept:18 Agustus 2021; Dipublish: 18 Agustus 2021 \\ *Corresponding author: E-mail: nafessa@staff.uma.ac.id
}

\begin{abstract}
Abstrak
Penelitian ini bertujuan untuk mengetahui pengaruh penggunaan handphone (Android) terhadap motivasi belajar siswa kelas XI SMA Negeri 1 Lintongnihuta. Penelitian ini adalah penelitian kuantitatif yaitu data yang diperoleh dengan bentuk angka-angka dengan analisis statistik. Populasi dalam penelitian ini adalah semua siswa kelas XI SMA Negeri 1 Lintongnihuta. Teknik pengambilan sampel menggunakan teknik random sampling yaitu 70 siswa dan teknik analisis data yang digunakan adalah analisis regresi linear sederhana. Berdasarkan analisis data, diperoleh bahwa hipotesis yang diajukan dalam penelitian ini dinyatakan diterima, yaitu ada pengaruh negative antara penggunaan handphone terhadap motivasi belajar siswa. Hal ini dibuktikan melalui perhitungan koefisien regresi sebesar 0,017 dengan nilai sig. 0,000. Perhitungan korelasi $\left(R_{x y}\right)=-0,436$ dengan Sig $<0,050$. Koefisien determinan $\left(\mathrm{R}^{2}\right)=0,190$ menunjukkan bahwa pengaruh penggunaan handphone terhadap motivasi belajar sebesar 19\%. Selanjutnya dilihat dari perhitungan mean hipotetik = 100 dan mean empirik 92,27 serta standart deviasi = 12,617 diketahui bahwa penggunaan handphone siswa tergolong sedang, sedangkan motivasi belajar dari perhitungan mean hipotetik = 75 dan mean empirik 59,44 serta standart deviasi 15,037 diketahui bahwa motivasi belajar siswa rendah.
\end{abstract}

Kata Kunci: Penggunaan Handphone; Motivasi Belajar

\begin{abstract}
A This study aims to determine the effect of using mobile phones (Android) on the learning motivation of class XI students of SMA Negeri 1 Lintongnihuta. This research is a quantitative research, namely the data obtained in the form of numbers with statistical analysis. The population in this study were all students of class XI SMA Negeri 1 Lintongnihuta. The sampling technique used was a random sampling technique of 70 students and the data analysis technique used was simple linear regression analysis. Based on data analysis, it was found that the hypothesis proposed in this study was accepted, namely that there was a negative influence between the use of cellphones on students' learning motivation. This is evidenced by the calculation of the regression coefficient of -0.017 with a sig value. 0.000. Calculation of correlation (Rxy) = -0.436 with Sig < 0.050. The coefficient of determinant (R2) $=0.190$ indicates that the effect of using mobile phones on learning motivation is 19\%. Furthermore, judging from the calculation of the hypothetical mean = 100 and the empirical mean 92.27 and the standard deviation =12.617, it is known that the students' mobile phone use is classified as moderate, while learning motivation from the calculation of the hypothetical mean $=75$ and the empirical mean is 59.44 and the standard deviation of 15.037 is known that learning motivation low students.
\end{abstract}

Keywords: Cellphone Use; Motivation to learn

DOI: https://doi.org/10.51849/j-p3k.v2i2.100

Rekomendasi mensitasi :

Nafessa. (2021), Pengaruh Penggunaan Handphone (Android) Terhadap Motivasi Belajar Siswa Kelas Xi Di Sma Negeri 1 Lintongnihuta. Jurnal Penelitian Pendidikan, Psikologi dan Kesehatan (J-P3K), 2 (2): 206-214. 


\section{PENDAHULUAN}

Dari generasi ke generasi handphone semakin berkembang menjadi semakin canggih. Handphone dengan kegunaan sederhana pada zaman dulu kini semakin dikembangkan menjadi sebuah alat yang serba bisa. Kegunaaan handphone bukan hanya sebatas alat telekomunikasi dengan suara dan tulisan (SMS) saja, kini handphone berevolusi menjadi barang yang unik. Handphone semakin lama mengalami kemajuan selain dapat berkomunikasi melalui suara kini handphone telah dilengkapi dengan aplikasi berkomunikasi dengan video call. Individu yang terpisah oleh jarak yang jauh kini bisa berbicara secara berhadapan dengan fungsi handphone yang semakin canggih.

Dampak dari revolusi handphone ini ada yang menguntungkan juga ada yang merugikan. Dampak positif dari semakin meningkatnya kegunaan handphone yaitu dengan mudahnya berkomunikasi serta handphone yang kini telah tersambung dengan jaringan internet mempermudah dalam pencarian informasi guna membantu pekerjaan maupun pembelajaran bagi siswa.

Semakin mudah dan murahnya handphone, sehingga semua pihak baik dari kelas ekonomi, status sosial, jenis kelamin bahkan usia sudah pernah menggunakan bahkan memiliki handphone itu sendiri. Handphone bukan sesuatu yang asing lagi. Bahkan anak prasekolah telah menikmati kegunaan dari alat komunikasi ini. Dampak negative dari penggunaan alat telekomunikasi ini banyak diperhatikan terutama dapat mempengaruhi hubungan secara langsung siswa.
Penggunaan perangkat Handphone memberikan tawaran informasi terhadap siswa SMA seperti menonton film, mendegarkan musik, mengakses permainan (games) dengan mudah, chatting dan browsing yang cukup menyita banyak waktu bagi mereka, sehingga menyebabkan waktu belajar akan berkurang dan dapat mengganggu konsentrasi belajar. Penggunaan aplikasi media sosial di dalam Handphone yang berlebihan dan di luar kontrol seperti facebook, Instagram, twitter, facebook, whatsapp, youtube dapat memangkas waktu yang seharusnya digunakan untuk belajar. Konsekuensi kebiasaan ini membuat siswa merasa bahwa belajar bukan fokus utama mereka.

Realitas ini mengganggu motivasi belajar mereka baik di sekolah maupun di rumah. Para Siswa yang memiliki motivasi belajar tinggi akan cenderung berupaya untuk mencapai prestasi. Ia mencoba menggunakan Handphone untuk belajar, misalnya dengan menggunakan fitur-fitur pendidikan seperti e-book, materi pembelajaran yang menarik yang bisa membantu motivasi belajar siswa. Sebaliknya, apabila siswa menggunakan Handphone secara intens untuk hal-hal yang kurang berkaitan dengan bidang akademis seperti seringnya bermain games, mengakses hiburan, dan kecanduan media sosial menjadi penghambat pada motivasi belajar siswa untuk mencapai prestasi. Bahkan perkembangan Handphone yang semakin menarik dan menyuguhkan fitur yang modern dapat menjadi daya tarik tersendiri sehingga anak-anak cenderung memilih menggunakan Handphone 
dibanding hal yang lain seperti belajar dan mengerjakan tugas-tugas.

Selain itu Adanya pergaulan teman sebaya dapat mempengaruhi intensitas penggunaan dan pemanfaatan handphone. Pemanfaatan handphone dikalangan siswa banyak yang disalah gunakan, banyak siswa yang menggunakan handphonetidak untuk memperluas wawasan pengetahuan melainkan untuk hal-hal yang lain,misalnya untuk membuka facebook, intenet, kamera, permainan (game). Hal tersebut akan mempengaruhi perkembangan perilaku anak, sehingga di jumpai para siswa membawa handphone saat pergi ke sekolah. Adanya siswa yang membawa handphoneke sekolah menyebabkan sebagian besar siswa menggunakan handphone di lingkungan sekolah. Biasanya siswa menggunakan handphone ketika waktu istirahat dan ketika siswa akan pulang sekolah.

Pemanfaatan handphone dikalangan siswa dapat mempengaruhi motivasi belajar siswa. Seperti yang diungkapkan Nyayu Khodijah (2014, p. 156) bahwa motivasi belajar adalah doronganyang menjadi penggerak dalam diri seseorang untuk melakukan sesuatu dan mencapai suatu tujuan yaitu untuk mencapai prestasi.

Dengan demikian, motivasi memiliki peran strategis dalam belajar, baik pada saat akan memulai belajar, saat sedang belajar, maupunsaat berakhirnya belajar. Asis Saefuddin \& Ika Berdiati, (2014, p. 8) mengemukakan bahwa dalam dunia pendidikan, belajar dapat dimaknai sebagai suatu proses yang sifatnya positif sehingga pada tahap akhirnya akan didapatkan keterampilan, kecakapan dan pengetahuan baru yang didapat dari akumulasi pengalaman dan pembelajaran. Hasil dari proses belajar tersebut diindikasikan dengan prestasi dan hasil belajar. Belajar sangat di perlukan adanya motivasi. Sedangkan motivasi yang kurang akan mengakibatkan siswa menjadi tidak tertarik untuk belajar, siswa menjadi cepat bosan, sehingga siswa malas untuk mengerjakan tugas yang diberikan oleh guru. Hasil belajar akan lebih optimal, jika ada motivasi. Makin tepat motivasi yang di berikan, akan semakin berhasil pula pelajaran itu. Selain itu penggunaan alat komunikasi handphone dan pergaulan teman sebaya akan mempengaruhi motivasi belajar siswa.

Situasi perilaku anak-anak yang sudah tercandu dengan Handphone secara langsung bisa mengganggu motivasi belajar dan membuat mereka sulit untuk berkonsentrasi dalam belajar. Berdasarkan hasil temuan awal di Sekolah SMA Negeri 1 Lintongnihuta menunjukkan bahwa realitas tersebut sudah menjadi masalah utama yang dapat mempengaruhi motivas belajar anak-anak. Handphone yang awalnya dapat membantu peserta dididik kini membawa masalah bagi motivasi belajar mereka. Dengan demikian, terjadi kesenjangan antara perilaku penggunaan Handphone dengan motivasi siswa di kelas XI SMA Negeri 1 Lintongnihuta.

Oleh karena itu, sangatlah penting untuk membuat kajian dan penelitian dalam rangka mengetahui seberapa besar pengaruh penggunaan Handphone terhadap motivasi belajar siswa siswa di kelas XI SMA Negeri 1 Lintongnihuta. Penelitian ini sangat urgent demi memperbaiki motivasi belajar anak-anak SMA yang saat ini mulai tidak fokus 
belajar dan justru hanya menghabiskan waktu mereka setiap hari dengan bermain Handphone baik di rumah maupun di sekolah.

Berdasarkan latar belakang dan urgensi masalah yang diuraikan maka dibuat suatu rencana penelitian dengan judul "Pengaruh Penggunaan Handphone Terhadap Motivasi Belajar siswa di kelas XI SMA Negeri 1 Lintongnihuta." Adapun rumusan masalah dalam penelitian ini adalah "apakah ada pengaruh penggunaan Handphone terhadap motivasi belajar siswa di kelas XI SMA Negeri 1 Lintongnihuta?" Sedangkan tujuan dari penelitian ini adalah untuk menganalisis dan mengatahui seberapa besar pengaruh penggunaan Handphone terhadap motivasi belajar siswa siswa di kelas XI SMA Negeri 1 Lintongnihuta.

\section{METODE PENELITIAN}

Penelitian in menggunakan pendekatan kuantitaif. Penelitian ini menggunakan metode deskriptif. Untuk penelitian lebih lanjut, analisis dilakukan dengan menggunakan metode analisis kuantitatif serta menggunakan sistem try out terpakai, artinya data yang sudah diambil dalam uji coba skala ukur, kembali digunakan sebagai data untuk pengujian hipotesis. Hal ini dilakukan sehubungan dengan terbatasnya jumlah subjek penelitian. metode ini digunakan dengan catatan apabila data uji coba skala ukur tidak memenuhi persyaratan validitas dan reliabilitas, maka penelitian ini tidak dapat dilanjutkan.

Teknik analisis data yang digunakan dalam penelitian ini adalah Analisis Regresi linear sederhana. Hal ini dilakukan sesuai dengan judul penelitian dan identifikasi variabel-variabelnya, dimana Analisis Regresi linear sederhana digunakan untuk menganalisis pengaruh antara satu variabel bebas dengan variabel terikat. Dalam penelitian ini yang menjadi variabel bebas $\mathrm{X}$ adalah penggunaan handphone dan menjadi variabel terikat $\mathrm{Y}$ adalah komunikasi interpersonal.

Jenis variabel yang digunakan adalah variabel bebas (independent variable) yaitu Handphone (X1) yang memiliki 5 indikator penelitian yakni ketekunan dalam belajar, ulet dalam menghadapi kesulitan, minat dan ketajaman perhatian dalam belajar, berprestasi dalam belajar, mandiri dalam belajar. Sedangkan variabel terikat (dependent variable) yakni motivasi belajar (Y) dengan 4 indikator penelitian: intensitas penggunaan dan kepemilikan Handphone, dampak negatif penggunaan Handphone, dampak positif penggunaan Handphone, dan proses belajar siswa di sekolah.

Penelitian dilaksanakan di SMA Negeri 1 Lintongnihuta Kabupaten Humbang Hasundutan. SMA Negeri 1 Lintongnihuta berdomisili di Jl. Melanton Siregar no 1 Lintongnihuta Kabupaten Humbang Hasundutan. Pelaksanaan uji coba kedua skala ini, dilakukan pada tanggal 06 April 2017 sampai 7 April 2017 siswa kelas XI berjumlah 70 orang di SMA negeri 1 Lintongnihuta. Pelaksanaan pengambilan data dalam rangka uji coba ini dilakukan dengan cara memberikan alat ukur pada siswa kelas XI di SMA negeri 1 Lintongnihuta. Sebelum para siswa mengisi alat ukur peneliti menjelaskan tujuan dari dilakukannya penelitian ini dan bagaimana petunjuk 
pengisiannya sehingga para siswa tidak merasa bingung. Setelah mereka selesai mengisi maka alat ukur akan di kumpul kepada peneliti.

\section{HASIL DAN PEMBAHASAN}

Hasil Analisis regresi linear sederhana dalam penelitian ini digunakan untuk menguji kebenaran hipotesis yang diajukan. Hipotesis dalam penelitian ini adalah ada pengaruh yang signifikan antara penggunaan handphone terhadap motivasi belajar siswa. Pembuktian kebenaran hipotesis tersebut, peneliti menggunakan analisis regresi linear sederhana. Asumsi yang digunakan adalah apabila nilai koefisien regresi memiliki tingkat probabilitas < 0,05 ( $\alpha 5 \%)$ maka hipotesis diterima, sebaliknya apabila nilai koefisien regresi linear sederhana memiliki tingkat probabilitas $>0,05$ ( $\alpha 5 \%)$ maka hipotesis ditolak. Analisis regresi linear sederhana menggunakan bantuan komputer program SPSS for windows dan diperoleh hasil sebagai berikut:

Tabel 1 Anova.

\begin{tabular}{llll}
\hline Model & Mean & F & Sig \\
\hline Regression & 2959.603 & 15.919 & $.000^{\mathrm{a}}$ \\
\hline
\end{tabular}

Analisis regresi linear sederhana menunjukkan adanya pengaruh penggunaan handphone yang signifikan dengan komunikasi interpersonal dengan melihat ANOVA dimana angka pada kolom signifikan menunjukkan 0,000 yang lebih kecil daripada $\alpha=0,05(0,000<0,05)$.

Tabel 2 Model Summary.

\begin{tabular}{llll}
\hline Model & $\mathrm{R}$ & R Square & Sig. \\
\hline 1 & $-.436^{\mathrm{a}}$ & .190 & .000 \\
\hline Keterangan & & \\
R : Nilai Koefisien Korelasi & \\
R Square : Model Regresi yang dibentuk
\end{tabular}

Dari table $\mathrm{X}$ diatas diketahui bahwa nilai $\mathrm{R}$ square adalah 0,190 (adalah pengkuadratan dari koefisien korelasi). $\mathrm{R}$ square dapat disebut koefisien determinasi yang dalam hal ini berarti 19\% jumlah penggunaan handphone mempengaruhi motivasi belajar. Ini berarti masih terdapat $81 \%$ pengaruh dari faktor lain terhadap komunikasi interpersonal, diantaranya adalah yang tidak disebutkan dalam penelitian ini.

Tabel 3 Uji Regresi Linear Sederhana

\begin{tabular}{llll}
\hline Model & $\mathrm{B}$ & $\mathrm{T}$ & Sig \\
\hline (constan) & .752 & 36.632 & .995 \\
Penggunaan & -0.017 & -.006 & .000 \\
Handphone & & & \\
\hline
\end{tabular}

Berdasarkan hasil perhitungan Analisis Regresi linear sederhana diatas, dapat diketahui bahwa terdapat pengaruh yang sangat signifikan antara penggunaan handphone terhadap motivasi belajar. Hasil ini dibuktikan dengan nilai signifikan sebesar 0,000 0,05 maka disimpulkan Ho ditolak dan Ha diterima, yang artinya ada pengaruh yang signifikan penggunaan handphone terhadap motivasi belajar. Hasil regresi linear sederhana signifikan $0,000<0,05$. Berdasarkan hasil ini, maka hipotesis yang telah diajukan dalam penelitian ini, dinyatakan diterima. Berdasarkan hasil uji regresi linear sederhana di atas maka terdapat persamaan regresi sebagai berikut:

$$
\hat{Y}=0,752 \mathrm{X}-0,017
$$

Persamaan garis linear sederhana tersebut dapat dijelaskan sebagi berikut:

1. $\alpha$ merupakan bilangan koefisien predictor. Nilai $\alpha$ yang besarnya menyatakan bahwa jika variabel independen dianggap konstan, maka penggunaan handphone sebesar 0,752 
2. $\beta$ merupakan koefisien regresi dari penggunaan handphone koefisien regresi -0,017 menyatakan bahwa setiap penambahan variabel penggunaan handphone sebesar 1 maka hal ini akan menyebabkan kenaikan Y sebesar -0,017.

Uji t digunakan untuk mengetahui apakah masing-masing variabel mempunyai pengaruh yang signifikan. Sig $<0,05$ yang artinya Ho ditolak. Sehingga hasilnya Ha diterima yang berbunyi "semakin besar penggunaan handphone maka motivasi belajar semakin sedikit pada siswa kelas XI SMA negeri I Lintongnihuta".

Hasil perhitungan Mean hipotetik variabel penggunaan handphone, jumlah butir yang dipakai adalah sebanyak 40 butir yang diformat dengan skala likert 4 pilihan jawaban, maka mean hipotetiknya adalah $\left\{(40 \times 1)+\left(\begin{array}{lll}40 & X & 4\end{array}\right)\right\}: 2=100$. Sementara itu untuk motivasi belajar, jumlah butir yang dipakai sebanyak 30 butir yang diformat dengan skala Likert 4 pilihan jawaban, maka mean hipotetiknya adalah $\{(30 \times 1)+(30 \times 4)\}: 2=75$.

Hasil perhitungan Mean Empirik Berdasarkan analisis data, diketahui bahwa mean empirik penggunaan handphone, mean empirik yang diperoleh sebesar 92,27 dengan bilangan SD sebesar 12,617, sedangkan untuk motivasi belajar adalah 59,44 dengan bilangan SD sebesar 15,037.

Berdasarkan kriteria dalam upaya
untuk menentukan penggunaan handphone dan motivasi belajaryang dilakukan oleh siswa kelas IX SMA negeri 1 Lintongnihuta, maka perlu dibandingkan antara mean/nilai rata-rata empirik dengan mean/nilai rata-rata hipotetik dengan mempehatikan besarnya bilangan SD dari masing-masing variabel yang sedang diukur.

Variabel penggunaan handphone apabila mean/nilai rata-rata hipotetik < mean/nilai rata-rata empirik, dimana selisihnya melebihi 12.617, maka dinyatakan bahwa penggunaan handphone yang diterima tinggi, dan apabila mean/nilai rata-rata hipotetik > mean/nilai rata-rata empirik, dimana selisihnya melebihi 12.617, maka dinyatakan bahwa penggunaan handphone rendah. Kemudian apabila mean/nilai rata-rata empirik dengan mean/nilai ratarata hipotetiknya selisihnya tidak melebihi bilangan 12.617, maka motivasi belajar yang diterima dinyatakan sedang / normal.

Untuk motivasi belajar, apabila mean/nilai rata-rata hipotetik < mean/nilai rata-rata empirik, dimana selisihnya melebihi 15.037, maka dinyatakan bahwa motivasi belajar yang dimiliki tinggi, dan apabila mean/nilai rata-rata hipotetik > mean/nilai rata-rata empirik, dimana selisihnya melebihi 15.037, maka dinyatakan bahwa motivasi belajar yang dimiliki rendah. Kemudian apabila mean/nilai rata-rata empirik dengan mean/nilai rata-rata hipotetiknya selisihnya melebihi bilangan 15.037, maka motivasi belajar yang dimiliki dinyatakan sedang / normal.

Tabel 4 Mean Hipotetik \& Empirik.

\begin{tabular}{|c|c|c|c|c|}
\hline \multirow[t]{2}{*}{ Variabel } & \multirow[t]{2}{*}{ SD } & \multicolumn{2}{|c|}{ Nilai Rata-rata } & \multirow[t]{2}{*}{ Keterangan } \\
\hline & & Hipotetik & Empirik & \\
\hline $\begin{array}{l}\text { Penggunaan } \\
\text { Handphone }\end{array}$ & 12.617 & 100 & 92,27 & $\begin{array}{l}\text { Penggunaan } \\
\text { handphone } \\
\text { sedang }\end{array}$ \\
\hline $\begin{array}{l}\text { Motivasi } \\
\text { Belajar }\end{array}$ & 15.037 & 75 & 59.44 & $\begin{array}{l}\text { Motivasi } \\
\text { belajar } \\
\text { rendah }\end{array}$ \\
\hline
\end{tabular}

Berdasarkan perbandingan kedua nilai rata-rata diatas (mean hipotetik dan 
mean empirik), maka dinyatakan bahwa penggunaan handphone para siswa kelas XI SMA negeri 1 Lintongnihuta tergolong sedang, sebab mean hipotetik (100) lebih besar dari mean empiriknya $(92,27)$ dan selisihnya melibihi bilangan SD $(12,617)$. Dalam hal motivasi belajar siswa kelas XI SMA negeri 1 Lintongnihuta dinyatakan memiliki motivasi belajar yang rendah, sebab mean hipotetiknya (75) lebih besar dari mean empiriknya $(59,44)$ dan selisihnya melebihi bilangan SD $(15,037)$.

Hasil penelitian ini membuktikan bahwa terdapat hubungan yang negatif antara penggunaan handphone terhadap motivasi belajar pada siswa kelas XI SMA Negeri 1 Lintongnihuta. Klasifikasi ini berdasarkan atas nilai korelasi $=-436$; Sig $<0,05$. Artinya semakin tinggi penggunaan handphone maka semakin rendah motivasi belajar yang dilakukan, sebaliknya semakin rendah penggunaan handphone maka semakin tinggi motivasi belajar yang dilakukan.

Dalam penelitian ini ditemukan bahwa motivasi belajar pada siswa kelas XI SMA Negeri 1 Lintongnihuta tergolong rendah. Pembelajaran digital menggunakan handphone dengan baik bisa meningkatkan motivasi belajar siswa. handphone bisa meningkatkan motivasi belajar siswa apabila digunakan sebagai media pembelajaran digital. Ming Hun Lin, dkk (2017) menegaskan bahwa pembelajaran digital memberikan pengaruh yang positif terhadap motivasi belajar siswa dan juga dapat meningkatkan hasil belajar siswa SMA.

Dalam teori motivasi dan pembagiannya, penggunaan handphone menjadi salah satu contoh motivasi ekstrinsik di mana hal atau keadaaan yang datang dari luar individu siswa yang mendorongnya untuk melakukan kegiatan belajar. Penggunaan handphone termasuk faktor dari luar siswa SMA yang mempengaruhi motivasi belajar mereka. Ketergantungan siswa pada handphone secara langsung membuat mereka malas belajar.

Pada dasarnya dalam belajar sangat diperlukan adanya motivasi (Habibi et al., 2018). Sedangkan motivasi yang kurang akan mengakibatkan siswa tidak tertarik untuk belajar, menjadi bosan, sehingga malas untuk mengejarkan tugas yang diberikan guru. Dengan kata lain, hasil belajar akan lebih optimal, jika ada motivasi. Ada banyak alasan mengapa siswa lebih termotivasi ketika siswa menggunakan handphone dalam pembelajaran. Liu (2016) dalam penelitiannya kepada 31 guru di sekolah dasar dalam pembelajaran di kelas menunjukkan 31,1 \% mereka menjawab alasan mereka menggunakan teknologi dalam pembelajaran adalah untuk membantu keterlibatan dan motivasi belajar siswa SD di kelas (Francis, 2017, p. 17).

Thomas, O'Bannon dan Bolton (2013) dalam penelitian mereka menemukan bahwa ponsel dapat meningkatkan pembelajaran siswa. Mereka menemukan bahwa 59\% ponsel dapat membantu meningkatkan keterlibatan dan motivasi belajar siswa. Hasil penelitian ini sejalan dengan hasil penelitian yang teliti oleh Gardenia Augusta (2018) yang menegaskan bahwa penggunaan smartphone pada mahasiswa memiliki pengaruh terhadap motivasi belajar mereka sebesar $4.3 \%$ dan sisanya 
95.7 dipengaruhi variabel lain dengan tingkat signifikansi sebesar 0,037.

Menurut Augusta mahasiswa dewasa ini cenderung selalu menggunakan handphone mereka dibandingkan membaca buku. handphone hanya digunakan sebatas browser data, internet, dan game. Realitas ini serupa dengan hasil penelitian Satriawanati (2017:60) bahwa anak menjadi terabaikan lewat kasing sayang palsu yang diberikan orang tua dengan cara memberikan dan menyediakan fasilitas kepada anak mereka berupa smartphone, bermain game, menonton TV secara berlebihan. Hal ini membuat anak menjadi malas belajar, lebih menyukai yang instan bahkan bisa membuat hasil belajar menjaid rendah

Penelitian ini membuktikan bahwa motivasi belajar yang dilakukan oleh siswa kelas XI SMA Negeri 1 Lintongnihuta tergolong sedang, $19 \%$ diantaranya disebabkan oleh penggunaan handphone yang dilakukan oleh siswa. Hal ini berarti masih terdapat $81 \%$ daripengaruh faktor lain yang tidak disebutkan dalam penelitian ini.

Hasil lain yang diperoleh dari penelitian dapat dilihat perbandingan mean hipotetik dan mean empiric dari masing-masing variable yaitu terlihat bahwa komunikasi interpersonal tergolong rendah dengan mean hipotetiknya sebab mean hipotetiknya 75.00 lebih besar dari mean empiriknya 59,44 . Sementara penggunaan handphone para siswa kelas XI SMA negeri 1 Lintongnihuta, dengan mean hipotetik (100) lebih besar dari mean empiriknya 92,27 maka dapat ditarik kesimpulan bahwa penggunaan handphone siswa tergolong sedang.

Kondisi sosial atau penggunaan handphone yang tergolong sedang ini, diasumsikan pada pemikiran bahwa isu yang beredar dimasyarakat tentang penggunaan handphone semakin tinggi di kalangan siswa mempengaruhi motivasi belajar memang benar. Hasil dari penelitian ini menunjukkan bahwa penggunaan handphone siswa yang tergolong sedang, sedangkan motivasi belajar antar siswa tergolong rendah.

\section{SIMPULAN}

Berdasarkan hasil analisis yang telah diuraikan, maka penelitian ini menghasilkan kesimpulan sebagai berikut: Penggunaan handphone memiliki pengaruh terhadap motivasi belajar siswa SMA Negeri 1 Lintongnihuta meskipun tingkat pengaruhnya masih tergolong rendah yakni $5.7 \%$ dengan tingkat signifikansi 0,028. Begitupun dengan hasil pengujian $t$ tabel lebih besar dari pada $t$ hitung yakni thitung $=2.232 \geq(\mathrm{ttab})=$ 1.989, maka Ho ditolak dan menerima Ha. Dengan demikian, dapat dinyatakan bahwa koefisien regresi adalah berarti. Artinya bahwa penggunaan handphone berpengaruh terhadap motiivasi belajar siswa.

\section{DAFTAR PUSTAKA}

Bambang Prasetyo dan Lina Miftahul Jannah. 2014. Metode Penelitian Kuantittatif, Teori dan Aplikasi. Jakarta: PT RajaGrafindo Persada.

Cleopatra, Maria. 2015." Pengaruh Gagya Hidup dan Motivasi Belajar Terhadap Prestasi Belajar Matematika." Dalam Jurnal Formati: Jurnal Ilmiah Pendidikan Vol 5.No 2 (2015), http://journal.lppmunindra.ac.id/index. php/Formatif/article/ view/336/321 
Fadillah, Ahmad., 2011 Pengaruh Penggunaan Alat Komunikasi Handphone (HP) terhadap aktifitas Belajar Siswa SMA Negeri 66 Jakarta Selatan. Skripsi. Fakultas Tarbiyah dan Ilmu Keguruan UINSH

Fatima, Siti dan Yusuf Muti. 2014. "Pengembangan Media Pembelajaran IPA-Fisika Smartphone Berbasis Android sebagai Penguat Karakter Sains Siswa." Dalam Jurnal Kurnia, https://www.neliti.com/publications/1 04179/pengembangan-media. pembelajaran-ipa-fisikasmartphoneberbasis-android-sebagai-p

Francis, James. 2017. “The Effect of Technology On Student Motivation and Engagement in Classroom-Based Learning," dalam Theses and Dissertation Educational Leadership, University of New England.

Garedina. 2018. "Skripsi: Pengaruh Penggunaan Smartphone Terhadap Prestasi Belajar Mahasiswa melalui motivasi belajar Mahasiswa." Universitas Sanata Dharma, Program Studi Pendidikan Ekonomi, Yogyakarta.

Habibi, M., Chandra, C., Mahyuddin, R., \& Hendri, S. (2018). Validity of Teaching Materials for Writing Poetry Based on Creative Techniques in Elementary Schools. Mimbar Sekolah Dasar, 5(3), 145-154. ttps://doi.org/10.17509/mimbar sd. v5i3.14501

Hasanah \& Kumalasari. 2015. Penggunaan Handphone dan Hubungan Teman pada Perilaku Sosial Siwa SMP Muhammadiyah Luwuk Sulawesi Tengah. Pendidikan IPS. Volume 2 No. 1. (Jurnal)

Hendrastomo, G. 2008. Jurnal Sosia, Representasi Telepon Seluler dalam Relasi Sosial. (diakses 28 Februari 2017)

http://physicedu.blogspot.co.id/20o9/o8/validitas -konsep-validitas-menurut.html?m=1 (diakses 21 januari 2017)

http://id.mwikipedia.org/wiki/Android_(sistem_o perasi) diakses tanggal 27 maret 2017

Irianto, H Agus. 2010. Statistik: Konsep Dasar Aplikasi dan Pengembangannya. Jakarta. Penerbit Prenada Media

Khodijah, N. (2014). Psikologi Pendidikan. PT Raja Grafindo Persada.

Mardhiyatun, Ibda. 2015. Penggunaan Smartphone dalam Meningkatkan Minat Berkonsultasi Siswa SMA N. 2 Wonosari. Skripsi. Online. Diakses tanggal 12 Februari 2017
Oktavia, Nova. 2012. Sistematika Penulisan Karya Ilmiah. Yogyakarta: Deepublish

Prastiwi, Citra. 2011. Hubungan antara Penggunaan Situs Jejaring Sosial dengan Motifasi Kerja Karyawan di BTPN Cabang Putri Hijau Kecamatan Medan Timur. Skripsi., (tidak dipublikasikan) Fakultas Psikologi Universitas Medan Area

Saefuddin, A., \& Ika, B. (2014). Pembelajaran Efektif. Pt. Remaja Rosdakarya.

Sandarmawan, Nur. 2015. Perbedaan Random Sampling dan Non-Random Sampling. Blog Campuran (on-line). Diakses tanggal 19 januari 2017 dari hhtp://nursandarmawan.blogspot.co.id

Utaminingsih, Astari Ina. 2006. Pengaruh Penggunaan Ponsel pada Remaja terhadap Interaksi Sosial Remaja. Skripsi. Dipublikasikan. Fakultas Pertanian ITB

Wikipedia. Diakses pada tanggal 19 januari 2017 dari https://id.m.wikipedia.org/wiki/Telepon_g engam 